Reprod. Nutr. Dévelop., 1980, 20 (5 A), 1461-1466.

\title{
The relationship between surface tension and release of rat jejunal brush border membrane hydrolases induced by sodium deoxycholate
}

\author{
par Monique VASSEUR ****, Annie POUSSE *, G. FERARD ** \\ * Unité de Recherches 61 de l'INSERM, avenue Molière, \\ 67200 Strasbourg. \\ ** Service de Biochimie, UER des Sciences Pharmaceutiques, \\ Université Louis Pasteur, 74, route du Rhin, \\ 67048 Strasbourg. \\ *** Present address : Centre de Recherches sur la Nutrifion, \\ CNRS, 9, rue Jules Hetzel, 92190 Meudon, France.
}

Summary. Rat jejunum was perfused in vivo with sodium deoxycholate concentrations ranging from 0.125 to $4 \mathrm{mM}$. The release of total protein and some brush border hydrolases (sucrase, maltase, leucine aminopeptidase and alkaline phosphatase) was followed as a function of both the time and the deoxycholate concentration.

1. Protein and enzyme release increased during deoxycholate perfusion only at concentrations greater than $0.5 \mathrm{mM}$. For each case, a plateau was reached at $2 \mathrm{mM}$ deoxycholate.

2. After removal o deoxycholate from the perfusion fluid, the rate of protein and enzyme release dropped to the control levels. Following perfusion with $0.125 \mathrm{mM}$ deoxycholate, however, there was a stabilizing effect so that the release rate of sucrase, maltase and alkaline phosphatase (but not of protein and leucine aminopeptidase) was smaller than that of the controls.

3. Protein and enzyme release was correlated with the deoxycholate-induced changes in surface tension. Significant increases in the release rates began between 0.5 and $1 \mathrm{mM}$ deoxycholate when the surface tension fell below 50 dynes $/ \mathrm{cm}$. The plateau observed at or above $2 \mathrm{mM}$ deoxycholate coincided with the stabilization of surface tension at 46 dynes $/ \mathrm{cm}$.

4. The maximum releasing effect also coincided with the critical micellar concentration of deoxycholate (1.5-2.5 $\mathrm{mM})$.

\section{Introduction.}

Among the neutral detergents, sodium deoxycholate (DOC) seems to be particularly suitable to study the structure and function of biological membranes (Philippot, 1971 ; Butters and Hughes, 1974), and more especially the brush border membrane of the small intestine. Firstly, it offers the advantage of being a physiological detergent which is present in jejunal intraluminal contents in normal as well as in disease states 
(Gracey ef al., 1971). Secondly, it is known to be a good solubilizing agent for membrane proteins in general while it usually has little effect on most enzyme activities (Butters and Hughes, 1974 ; Critchley ef al., 1975).

Critchley et al. (1975) have shown that in vitro $20 \mathrm{mM}$ DOC has an efficient solubilizing effect on proteins of the hamster brush border membrane. On the other hand, we have demonstrated by an in vivo perfusion technique that $2 \mathrm{mM} \mathrm{DOC}$ has a strong extracting effect on rat brush border enzymes (Vasseur ef al., 1978), while $0.125 \mathrm{mM}$ DOC has no immediate effect (Vasseur ef al., 1979).

In the present paper, we sought to enlarge this information by using DOC concentrations in the range from 0.125 to $4 \mathrm{mM}$. The choice of this concentration range was based on the following : (i) in the rat, the physiological levels of unconjugated dihydroxy-bile salt DOC vary from 0.1 to $0.3 \mathrm{mM}$ and (ii) DOC levels increase (range : 0.8 to $5 \mathrm{mM}$ ) under certain pathological conditions, as for instance, in the syndrome of temporary monosaccharide malabsorption (Gracey et al., 1971 ; Keeling ef al., 1976). In order to clarify the possible mechanisms underlying the action of DOC on brush border enzymes, we have studied the relationship between surface tension, critical micellar concentration (CMC) and enzyme release.

\section{Material and methods.}

Experimental procedure. - Male Wistar rats $(280-320 \mathrm{~g})$, fasted overnight with water ad libitum, were anaesthetized with sodium pentobarbitone $(5 \mathrm{mg} / 100 \mathrm{~g}$ of body weight). After laparotomy, a proximal jejunal segment (about $20 \mathrm{~cm}$ in length) was cannulated then perfused with Krebs Henseleit bicarbonate buffer ( $\mathrm{pH}=7.0$; $37{ }^{\circ} \mathrm{C}$; Krebs and Henseleit, 1932) at a constant rate of $0.5 \mathrm{ml} / \mathrm{min}$. The jejunal segment was covered with moist gauze and the animal was kept in a room thermostated at $37^{\circ} \mathrm{C}$.

All perfusions lasted $180 \mathrm{~min}$. After initial equilibration from 0 to $30 \mathrm{~min}$, the perfusate was collected at 10 min intervals to monitor protein and enzyme release versus time. Between the 60 th and 90 th min, the intestine was perfused with buffer containing DOC in the following concentrations $(\mathrm{mM}): 0(n=17) ; 0.125,0.25,0.5$ and $1.0(n=10$ in each group) ; $2.0(n=12)$ and $4.0(n=3)$.

The fractions collected were stored at $4^{\circ} \mathrm{C}$ for protein and enzyme analyses which always took place within $12 \mathrm{hrs}$. Sucrase and maltase were assayed according to Dahlqvist (1968), leucine aminopeptidase according to Maroux ef al. (1973), alkaline phosphatase according to Hausamen ef al. (1967) and protein according to Lowry ef al. (1951) with bovine serum albumin as standard. It was verified that DOC at the concentrations used did not affect any of the enzyme activities under study.

Expression of results. - Enzyme activities were expressed in international units (1 unit $=1 \mu$ mole of substrate hydrolyzed per min under our experimental conditions). The DOC-induced release of total protein $(\mathrm{mg} / 10-\mathrm{min}$ fraction) and total enzyme activities (milli-Units per fraction) were plotted as a function of time. Straight lines were fitted by linear regression and the slopes thus obtained were compared by covariance analysis. 
Determination of the critical micellar concentration (CMC). - The CMC of the DOC solutions was determined by measuring (i) the scattered light with a thermostated $\left(37{ }^{\circ} \mathrm{C}\right)$ nephelometer equipped with a laser source $(632.8 \mathrm{~nm})$ and (ii) the surface tension with a stalagmometer. The solutions were prepared by dissolving the DOC either in buffer alone or in buffer collected between 60 and 100 min from animals perfused without DOC.

\section{Results and discussion.}

Patterns of protein and hydrolase release. - The patterns of protein and maltase release as functions of both time and DOC concentration are given in figure 1. Similar results were found for other hydrolases (sucrase, alkaline phosphatase and leucine aminopeptidase) but are not shown.
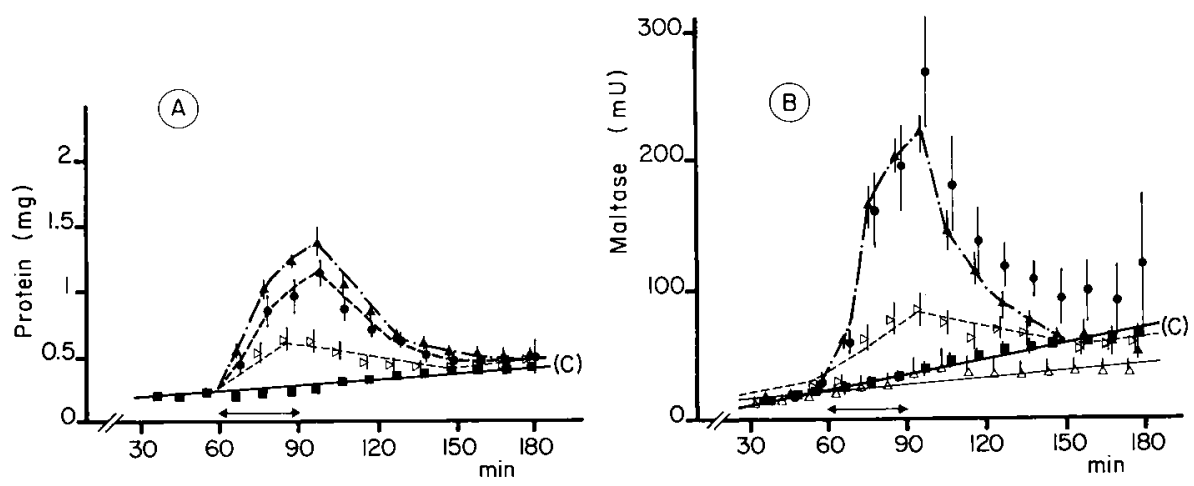

FIG. 1. - Release of protein and maltase activity from the rat jejunal brush border membrane as a function of time and DOC concentration. A : Protein (mg per 10-min fraction) ; B : Maltase activity (total $\mathrm{mU}$ per fraction). SEM values are indicated by the vertical bars. Between 60 and 90 min (horizontal double arrow), DOC was added to the perfusion fluid at the following concentrations ( $\mathrm{mM}$ ) : $0(n, n=17) ; 0.125(\Delta, n=10) ; 1.0(\triangleright, n=10) ; 2.0(X, n=12)$ and $4.0(\bullet, n=3)$. The straight lines, corresponding to the groups at 0.25 and $0.5 \mathrm{mM} \mathrm{DOC}$, are indistinguishable from the control without DOC (line C) and are not shown.

During detergent perfusion $(60-90 \mathrm{~min})$, the release rate only increased significantly when the DOC concentration was $1 \mathrm{mM}$ or higher. An apparent plateau was reached at $2 \mathrm{mM}$ since the release patterns with 2 and $4 \mathrm{mM} \mathrm{DOC}$ were not significantly different. The DOC-induced protein and enzyme release was reversible. Protein and enzyme levels in the perfusates diminished and became indistinguishable from the control values about $50 \mathrm{~min}$ after DOC perfusion was interrupted.

Af DOC concentrations between 0 and $0.5 \mathrm{mM}$, the release of both enzyme and total protein was linear with a slope significantly different from zero $(P<0.01)$. There was no difference in the slope of those lines at $D O C=0,0.25$ and $0.5 \mathrm{mM}$. But at $0.125 \mathrm{mM} \mathrm{DOC}$ the slope was significantly less for sucrase, maltase and alkaline phosphatase (not for protein or leucine aminopeptidase). This confirms and extends 
previous observations suggesting an in vivo stabilizing effect of low $(0.125 \mathrm{mM}) \mathrm{DOC}$ concentrations on the brush border membrane (Vasseur ef al., 1979).

Furthermore, our data show that relatively high levels of DOC (1-4 $\mathrm{mM})$ had a direct action on the brush border membrane. Such DOC levels have been observed under certain pathological conditions (Gracey et al., 1971). Other authors have reported that in vivo a 2-5 mM luminal concentration of DOC inhibited the uptake of water and a variety of water-soluble substances such as electrolytes and monosaccharides (Harries and Sladen, 1972 ; Sladen and Harries, 1972 ; Teem and Phillips, 1972). These in vivo functional effects on the digestive and absorptive processes were probably not due to gross morphological damage. No effects on the mucosal structure as examined by light microscopy were seen either at $1 \mathrm{mM}$ (Keeling et al., 1976 ; Shiner, 1969 ; Teem and Phillips, 1972) or at 2 mM DOC (Clark ef al., 1967 ; Vasseur et al., 1978). In the following paragraph, we describe some experiments designed to explain the possible physico-chemical interactions underlying DOC-induced enzyme release.

Correlation between surface tension and DOC releasing effects. - To examine how the DOC effects described here are related to its surfactive properties, the surface tension of DOC solutions was measured. Those measurements (fig. 2) were not affected by the presence of proteins released from the intestinal tissue into the perfusates. In our conditions, the CMC occurred between 1.5 and $2.5 \mathrm{mM}$ DOC, which agrees with the values obtained by other workèrs using different buffers and methods (Jørgensen and Skou, 1971 ; Philippot and Authier, 1973).

Figure 2 also shows the relationship between surface tension and DOC-induced release of total maltase. Essentially identical results were found for protein, alkaline phosphatase and leucine aminopeptidase. It is seen that DOC had no action on enzyme release as long as the surface tension was more than 50 dynes $/ \mathrm{cm}$. Below this level,

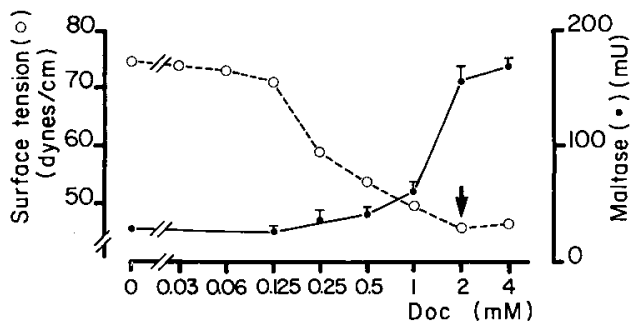

FIG. 2. - Relationship between enzyme release and surface tension as a function of DOC concentration. Ordinates : Maltase release (•, total $\mathrm{mU}$ for the $60-100$-min period) and surface tension (o, dynes/cm). Abcissa : DOC concentration ( $\mathrm{mM}$ ) in logarithmic scale. The vertical arrow indicates the CMC.

however, an abrupt increase in the rate of enzyme and protein release occurred. As the surface tension stabilized at 46.0-46.2 dynes $/ \mathrm{cm}$, enzyme and protein release reached a plateau coinciding with the CMC. From the results (fig. 2), and in agreement with Helenius' and Simons' (1975) concepts of detergent action on membranes, it is clear that enzyme and protein release from the intestinal brush border membrane occurs just prior to the attainment of the $C M C$, i.e. between 1 and $2 \mathrm{mM}$ DOC when the inactive monomers begin to associate into micelles. Jørgensen and Skou (1971) and Philippot et al. $(1971,1973)$ have also reported that the maximal activation of ATPase activity in the outer medulla of rabbit kidney or the human red blood cell membrane is obtained only when defergent concentration 
reaches the CMC. Above that concentration, ATPase activity drops progressively. Several authors have proposed that DOC micelles solubilize phospholipids by forming mixed micelles (Philippot, 1971 ; Carey and Small, 1970 ; Small ef al., 1979). These mixed micelles in turn would solubilize cholesterol (Kirkpatrick ef al., 1974). In view of these data, it would be interesting to determine (i) whether phospholipid and cholesterol appear in the intestinal lumen during DOC perfusion, and (ii) if release of these membrane components also reaches a plateau at $2 \mathrm{mM} \mathrm{DOC}$, the critical micellar concentration.

The present results strongly suggest that the key element determining protein release from the brush border membrane is the transition of the physical state of DOC from the monomeric to the micellar form. When the CMC is reached, protein release levels off.

Reçu en décembre 1979.

Accepté en mars 1980.

Acknowledgements. - The authors are indebted to Dr. F. Alvarado for constructive criticism and help in preparing the manuscript. Thanks are also due to Mrs. Suzanne Seige for secretarial assistance.

Résumé. Les effets in vivo du deoxycholate de sodium (DOC) sur le jéjunum de rat sont étudiés par une technique de perfusion luminale. La libération des protéines totales et de quelques hydrolases (sucrase, maltase, phosphatase alcaline et leucine aminopeptidase) de la bordure en brosse est suivie en fonction du temps, ef de la concentration en DOC $(0.125-4 \mathrm{mM})$.

1. La libération des protéines et des enzymes est significativement augmentée pour des concentrations de $D O C$ supérieures à $0.5 \mathrm{mM}$ et un plateau est atteint à partir de $2 \mathrm{mM}$.

2. L'effet du DOC est réversible. Cependant après la perfusion avec le DOC à une concentration de $0.125 \mathrm{mM}$, on note un effet stabilisant : la libération de sucrase, maltase et phosphatase alcaline (mais non de protéines ni de leucine aminopeptidase) est plus faible que celle des témoins.

3. La libération des protéines et des enzymes est liée à la tension superficielle du DOC: la libération des enzymes augmente lorsque la tension superficielle chute au-dessous de 50 dynes $/ \mathrm{cm}$. Le plateau observé à partir de $2 \mathrm{mM}$ de DOC coïncide avec la stabilisation de la tension superficielle à 46 dynes $/ \mathrm{cm}$.

4. La concentration de DOC pour laquelle la libération des enzymes est maximale coincide également avec la concentration micellaire critique du DOC (1.5-2.5 mM).

\section{References}

BUTTERS T. D., HUGHES R. C., 1974. Solubilization and fractionation of glycoproteins and glycolipids of KB cell membranes. Biochem. J., 140, 469-478.

CAREY M. C., SMALL D. M., 1970. The characteristics of mixed micellar solutions with particular reference to bile. Amer. J. Med., 49, 590-608.

CLARK M. L., LANZ M. C., SENIOR J. R., 1967. Bile salt regulation of fatty acid resorption and esterification in rat everted jejunal sacs in vitro and into thoracic duct lymph in vivo. J. clin. Invest., 48, 1587-1599.

CRITCHLEY R., HOWELL K. E., EICHHOLZ A., 1975. Solubilization of brush borders of hamster small intestine and fractionation of some of the components. Biochim. biophys. Acta, 394, 361-376.

DAHLQVIST A., 1968. Assay of intestinal disaccharidases. Analyf. Biochem., 22, 99-107. 
GRACEY M., BURKE V., OSHIN A., BARKER J., GLASCOW E. F., 1971. Bacteria, bile salts and intestinal monosaccharide malabsorption. Gut, 12, 683-692.

HARRIES J. T., SLADEN G. E., 1972. The effects of different bile salts on the absorption of fluid, electrolytes and monosaccharides in the small intestine of the rat in vivo. Gut, 13, 596-603.

HAUSAMEN T. U., HELGER R., RICK M., GROSS W., 1967. Optimal conditions for the determination of serum alkaline phosphatase by a new kinetic method. Clin. chim. Acta, 15, 241-245.

HELENIUS A., SIMONS K., 1975. Solubilization of membranes by detergents. Biochim. biophys. Acta, 415, $29-79$.

JØRGENSEN P. L., SKOU J. C., 1971. Purification and characterization of $\left(\mathrm{Na}^{+}+\mathrm{K}^{+}\right)$ATPase. I. The influence of detergents on the activity of $\left(\mathrm{Na}^{+}+\mathrm{K}^{+}\right)$ATPase in preparations from the outer medulla of rabbit kidney. Biochim. biophys. Acta, 233, 366-380.

KEELING J. W., LAMABADUSURIYA S. P., HARRIES J. T., 1976. The effects of pure and micellar solutions of different bile salts on mucosal morphology in rat jejunum in vivo. J. Pathol., 118, 157-163.

KIRKPATRICK F. H., GORDESKY S. E., MARINETT G. V., 1974. Differential solubilization of proteins, phospholipids, and cholesterol of erythrocyte membranes by detergents. Biochim. biophys. Acta, 345, 154-161.

KREBS H. A., HENSELEIT K., 1932. Untersuchungenüber die Harnstoffbildung im Tierkörper. Hoppe-Seylers Z. Physiol. Chem., 210, 33-66.

LOWRY O. H., ROSEBROUGH N. J., FARR A. L., RANDALL R., 1951. Protein measurement with the Folin phenol reagent. J. biol. Chem., 193, 265-275.

MAROUX S., LOUVARD D., BARATTI S., 1973. The aminopeptidase from hog intestinal brush border. Biochim. biophys. Acta, 321, 282-295.

PHILIPPOT J., 1971. Study of human red blood cell membrane using sodium deoxycholate. I. Mechanism of solubilization. Biochim. biophys. Acta, 225, 201-213.

PHILIPPOT J., AUTHIER M. H., 1973. Study of human red blood cell membrane using sodium deoxycholate. II. Effects of cold storage, EDTA and small deoxycholate concentrations on ATPase activities. Biochim. biophys. Acto, 225, 201-213.

SHINER M., 1969. Effect of bile acids on the small intestinal mucosa in man and rats : Light and electron microscope study. In L. SCHIFF, J. B. CAREY, J. DIETSCHY, Bile salt metabolism. C. C. Thomas, Springfield (III.), Vol. 1, 41-55.

SLADEN G. E., HARRIES J. T., 1972. Studies on the effects of unconjugated dihydroxy-bile salis on rat small intestinal function in vivo. Biochim. biophys. Acta, 288, 443-456.

SMALL D. M., PENKETT S. A., CHAPMAN D., 1969. Studies on simple and mixed bile salf micelles by nuclear magnetic resonance spectroscopy. Biochim. biophys. Acta, 176, 178-189.

TEEM M. V., PHILLIPS S. F., 1972. Perfusion of the hamster jejunum with conjugated and unconjugated bile acids : Inhibition of water absorption and effects on morphology. Gastroenterology, 62, 261-267.

VASSEUR M., FERARD G., POUSSE A., 1978. Rat intestinal brush border enzyme release by deoxycholate in vivo. Pflugers Arch., 373, 133-138.

VASSEUR M., FERARD G., POUSSE A., 1979. Do low doses of deoxycholate modify the release of rat jejunal brush border hydrolases? Pflügers Arch., 379, 297-299. 